\title{
MENDISKUSIKAN KEMBALI GENERASI METALHEAD 1980-AN DALAM KANCAH SUBKULTUR DI INDONESIA
}

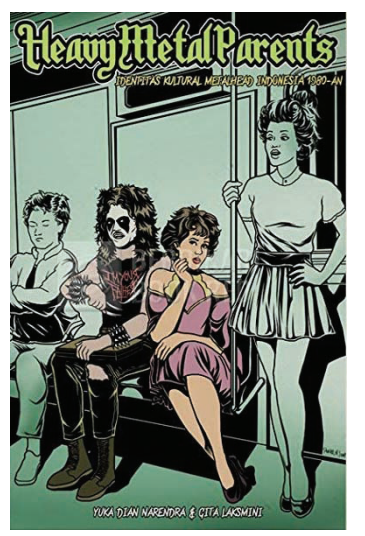

\section{Resensi}

Judul

Penulis

Penerbit

Jumlah

ISBN

Resensi
: Heavy Metal Parents - Identitas Kultural Metalhead Indonesia 1980-an

: Yuka Dian Narendra Mangoenkoesoemo

Gita Widya Laksmini Soerjoatmodjo

: Octopus Publishing

: 260 Halaman

: 978-602-727-439-6

: Unik Dian Cahyawati

Kehidupan para penggemar musik metal pada era 1980-an menarik untuk diperbincangkan kembali mengingat status mereka yang terbilang rumit di dalam ranah diskusi mengenai eksistensi subkultur terutama

subkultur penggemar musik metal. Musik rock selama ini memang menjadi ikon resistensi bagi kaum muda. Musik metal sebagai turunan dari musik rock bisa dikatakan juga sebagai resistensi terutama ketika memasuki era tahun 1990-an. Namun, bagaimana dengan penggemar musik metal pada tahun 1980an, apakah mereka juga melakukan resistensi sebagaimana yang dilakukan oleh para penggemar metal tahun 1990-an dan bagaimana konstruksi identitas kultural mereka adalah hal-hal yang melatar belakangi penulis untuk membuat buku berjudul "Heavy Metal Parents - Identitas Kultural Metalhead Indonesia 1980an" ini. Penulis melakukan penelitian pada penggemar musik metal tahun 1980-an dari kalangan menengah yang tinggal di Jakarta. Hal ini dilakukan karena Jakarta dianggap sebagai pusat berkembangnya musik metal pada masa itu. Konser-konser metal dari band metal Barat juga sering diadakan di Jakarta dan sekitarnya.

Musik rock sebagai akar dari heavy metal menjadi musik yang dilarang pada masa Orde Lama. Musik-musik yang datang dari Barat dianggap melemahkan semangat para kaum muda pada saat itu. Kaum muda menjadi konsumtif dan berakibat pada kurangnya kontribusi generasi muda pada Orde Lama untuk berpartisipasi dalam kegiatan politik untuk menentang neo-kolonialisme dan neoimperialisme. Modernisasi yang dimaksud oleh pemerintah pada saat itu adalah semangat anti Barat, sedangkan menurut para pemuda, modernisasi adalah dengan mengikuti perkembangan Barat untuk menjadi bagian dari masyarakat dunia, salah satunya yaitu dengan mendengarkan musik rock yang datang dari Barat. Hal ini ditentang oleh negara sehingga dengan mendengarkan musik rock merupakan sebuah resistensi.

Era Orde Baru selanjutnya membuka peluang untuk mengkonsumsi produk budaya Barat, meskipun demikian, Orde Baru tetap membatasi style yang dipakai oleh pemuda pada saat itu. Gaya penggemar musik metal yang kerap menampilkan style dengan rambut gondrong, celana kulit ketat, atau atribut lain khas metal sangat bertentangan dengan 'aturan' Orde Baru tentang penampilan rapi pada pemuda dengan potongan rambut pendek dan rapi. Hal yang menarik lainnya adalah ketika penikmat musik metal Indonesia 
harus menikmati kaset yang 'aspal' atau asli tapi palsu. Indonesia pada saat itu membajak kaset dari luar negeri, namun melalui usaha yang legal. Dalam kasus ini, penggemar musik metal tahun 1980-an merasa menjadi bagian dari metal dunia, tetapi tidak merasa sebagai bagian metal Indonesia. Pengalaman ini pula yang membedakan penggemar musik metal Indonesia dengan penggemar musik metal di negara-negara lain. Praktik menikmati musik heavy metal dengan kaset yang 'aspal' juga turut memunculkan pertanyaan yaitu apakah penikmat musik melalui kaset 'aspal' dapat digolongkan sebagai subkultur? Subkultur memiliki roda sosio-ekonominya sendiri, sedangkan pada saat itu konsumsi metal diasumsikan sebatas kesenangan mendengarkan dan memainkan musik metal tanpa pernah berhasil menciptakan subkulturnya. Resistensi yang terlihat samar dengan tidak terdengarnya penikmat metal era 1980-an pada kancah politik juga turut menambah daftar pertanyaan mengenai subkultur pada diri mereka.

Menurut penulis, penggemar heavy metal tahun 1980-an kemudian sering disebut ahistoris, keberadaan mereka seperti 'bandul' dengan status sosio kulturalnya yang tidak jelas. Dari hal tersebut kita menjadi tahu bagaimana status para metalheadt. Saat mereka muda, mereka melakukan apa yang disebut Althusser sebagai praktik self-regulation di mana para penikmat metal ini seolah-olah setuju bahwa sebagai penggemar musik heavy metal, mereka adalah anomali dan berbeda dengan masyarakat lain yang lebih umum dari beberapa aspek. Self-regulation ini muncul karena narasi pada Orde Baru. Pada saat memasuki era tahun 1990-an, generasi penggemar metal 1980-an ini kemudian sudah bertransformasi menjadi orang dengan usia dewasa. Sebagian dari mereka ada yang sudah menjadi orang tua dan memiliki anak sehingga pada tahun di mana heavy metal sudah mengalami kemajuan dan mulai 'terdengar' dalam semangat reformasi, generasi penikmat metal 1980-an sudah 'terlalu tua' untuk itu semua.
Sekarang, ketika heavy metal sudah mulai meredup, ketika sudah jarang melihat musisi dengan rambut gondrong dan celana kulit ketat, dan konser-konser metal sudah tidak sesering dulu diadakan, genarasi penikmat metal tahun 1980-an masih menjadikan metal sebagai musik yang mereka gemari. Para penggemar heavy metal 1980-an yang kebanyakan sudah menjadi orang tua dari anak-anak yang mulai beranjak remaja masih sering mendengarkan musik metal dan melakukan praktik yang terkait dengan musik metal, meskipun begitu, mereka menolak musik metal sebagai 'tembang kenangan'. Mereka tidak ingin menganggap bahwa musik metal sudah bukan merupakan bagian dari diri mereka dan hanya sebagai kenangan saja. Seperti yang tertulis pada buku ini, ada satu kalimat yang menggambarkan bagaimana generasi penikmat metal 1980-an memaknai musik metal pada saat ini, yaitu : Menghidupi kembali masa remaja yang diisi dengan mendnegarkan musik heavy metal bukan sebuah praktik nostalgia, tapi perayaan individualitas yang tertunda. Sebagian dari mereka juga menginginkan, kalau tidak bisa disebut sebagai menginginkan, anakanaknya untuk meneruskan kegemaran mereka yaitu mendengarkan musik metal karena musik metal lebih dari sekedar musik, namun banyak dimensi ekstra musikal seperti ideologi di dalam musik metal yang dianggap unik dan patut dilestarikan oleh anak-anak pra penggemar musik metal tahun 1980-an. Penulis benar-benar melakukan pendekatan pada setiap narasumber metalhead tahun 80-an hingga mengulik bagaimana harapan mereka terhadap kehidupan anak-anak mereka kelak terkait musik metal yang masih melekat pada diri meskipun era tersebut telah berlalu. Bagian itu merupakan salah satu hal yang cukup menarik mengingat perkembangan musik metal saat ini sudah mulai menjauh dari para remaja.

Buku ini bisa menjadi referensi bagi siapa saja yang memiliki minat pada ranah subkultur maupun kajian tentang musik metal terutama pada era 80-an. Melaui buku ini pembaca dapat melihat pergulatan identitas pada metalhead Indonesia di era tersebut. Buku 
Heavy Metal Parents - Identitas Kultural Metalhead Indonesia 1980-an sebenarnya tidak banyak membahas teori-teori neo subkultur dan mengaitkannya dengan praktik para metalhead, meskipun hal tersebut sebenarnya memungkinkan untuk dibahas. Namun, dengan adanya buku tersebut menjadikan catatan sejarah tersendiri bagi metalhead di Indonesia pada tahun 80-an yang nantinya bisa menjadi pendukung bahan kajian mengenai pergerakan penggemar musik underground lainnya. 